\title{
CONTROLS ON FLUVIAL SYSTEMS IN THE SIWALIK NEOGENE AND WYOMING PALEOGENE
}

WILLIS*, Brian J., BEHRENSMEYER, Anna Kay, Dept. of Paleobiology, Smithsonian Institution, Washington, D.C. 20560, U.S.A.; BOWN, Thomas M., USGS, Denver, CO 80225, U.S.A.; KRAUS, Mary, Dept. of Geological Sciences, Univ. of Colorado, Boulder, CO 80309, U.S.A.; BRIDGE, John S., and KHAN, Imran, Dept. of Geological Sciences, SUNY-Binghamton, NY 13902, U.S.A.

The 3-km thick Neogene Siwalik Group (Himalayan foredeep in northern Pakistan) and the 2-km thick Paleogene Fort Union/Willwood Formations (Bighorn Basin, Wyoming) both preserve long records of fluvial deposition adjacent to rising mountain belts. Depositional environments and associated habitats change with spatially varying physiography and deposition by river systems that may differ greatly in size, sediment loads, depositional rates, drainage of adjacent floodplains, and taphonomy of organic remains. At times, some environments may not be preserved; for example, avulsion of channels to low areas removes more deposits of channel-distal environments as avulsions increase relative to net sediment aggradation rates. Recognition of such large-scale biases is important because they represent time scales over which long term paleoecological change is reconstructed, and requires knowledge of how drainage systems changed in time and space within these evolving basins.

The Siwalik Group was deposited by large rivers that filled a basin extending at least $1000 \mathrm{~km}$ along its axis and 150-250 km away from the mountain front. Despite the scale of these rivers relative to Siwalik exposures, transitions between different fluvial systems have been recognized. For example, a 1-km thick sequence bridging the boundary between Chinji and Nagri formations records displacement of a smaller river system (width $<2 \mathrm{~km}$; depth 5-10 m; discharge $1000-1500 \mathrm{~m}^{3} / \mathrm{s}$ ) by a larger system (width $<5 \mathrm{~km}$; depth $15-30 \mathrm{~m}$; discharge at least $5,000-10,000 \mathrm{~m}^{3} / \mathrm{s}$ ), with an associated upsection increase (30 to $70 \%$ ) in the proportion of channel sandstones, increased mean sediment accumulation rates (150 to 300 $\mathrm{m} / \mathrm{my}$ ), decrease in poorly drained floodplain deposits and well developed paleosols, marked decrease in abundance of faunal remains, and a major change in faunal composition. Stratigraphically higher (Dhok Pathan Fm.), there is a lateral transition between deposits of dissimilar, coeval river systems with corresponding differences in local paleoenvironments and vertebrate taphonomy. Although upsection changes in environments and vertebrate faunas may generally reflect extrabasinal controls such as tectonism and climate change, our studies emphasize the importance of recognizing deposits from different contemporaneous river systems before inferring such large-scale controls on paleoenvironmental change through time.

The Bighorn Basin is an intermountain foreland basin extending $200 \mathrm{~km}$ along its axis and about $80 \mathrm{~km}$ across. A large portion of this basin is exposed, and thus it is possible to reconstruct the distribution of river systems and the spatial paleoenvironments in more detail than in the Siwaliks. The Bighorn Basin was traversed along its axis by an early Eocene, north-south flowing river that was joined by smaller rivers flowing transverse to the axis. The proportion of channel sandstones decreases upsection (50 to 25\%) from the Fort Union to the Willwood Fm. The proportion of channel sandstones and the abundance of well developed paleosols decrease with increasing net sediment aggradation rates. Although channel deposits are concentrated along the basin axis in a more complex way in some stratigraphic intervals, it is unclear to what extent these changes reflect deposition by different rivers versus extrinsically controlled changes within individual river systems. 